\title{
Study on the Suitability of Banana Varieties in Relation to Preparation of Chips
}

\author{
M. M. MOLLA ${ }^{1 *}$, T. A. A. NASRIN ${ }^{2}$ \& M. NAZRUL ISLAM ${ }^{3}$ \\ ${ }^{1,2 \& 3}$ Postharvest Technology Section, HRC, Bangladesh Agricultural Research Institute, Gazipur, \\ Bangladesh
}

\begin{abstract}
A study was conducted at Postharvest Technology Section, Horticulture Research Centre (HRC) under Bangladesh Agricultural Research Institute (BARI), Joydebpur, Gazipur during October 2007 to December 2008 to find a suitable variety for preparation of quality banana chips and their good packaging. Three banana varieties viz. Sabri, BARI Kola-1 and BARI Kola-2 and three packaging materials viz. low density polyethylene, medium density polyethylene and metalex foil pouch were selected for this. The fresh pulps of banana were analyzed for its nutritional composition like moisture content, protein, fat, reducing sugar, non- reducing sugar and total sugar. Based on taste testing panel, freshly prepared chips from Sabri kola scored first for its colour. For crispiness, BARI Kola-2 obtained the lowest score while Sabri and BARI Kola-1 showed the same score. There was no statistically difference for taste, flavour and overall acceptability of the products.
\end{abstract}

Key words: Banana chips, oil content, moisture content, packaging, sensory evaluation.

\section{INTRODUCTION}

Banana (Musa sapientum $\mathrm{L}$ ) is one of the major fruit crops in Bangladesh in respect of production and area (BBS, 2006). It is available throughout the year. Its consumption rate is higher than any other fruit. It is one of the cheapest, delicious and most nourishing of all fruits. It is preferred by people of all ages. The fruits constituents mainly carbohydrates, minerals and water and thus is a rich source of energy. It has also several medicinal properties. Banana is a perishable fruit and considerable amount of it is spoiled. The perishability of the fruit is attributed to immense physiological changes after harvest (Momen et al., 1993). The magnitude of post harvest losses in fresh fruits including banana in Bangladesh is 25-50\% (Amiruzzaman, 1990), whether it is only 5$25 \%$ in developed countries (Khader, 1992).

Chips are the most popular snack item in many fast food outlets. Fried banana chips may be one of the important potential banana products in Bangladesh. Banana chips may be also easily salable snack food in the markets. For longer shelf life, crispiness and chips quality moisture content is the most important factor as far as storage stability is concerned. Bacteria and other microorganism cannot grow easily in lower percentage of moisture content in chips. Visual colour is the major quality criterion for determining the commercial quality with respect to consumers' preferences and cost of the chips (Anand et al., 1982). Packaging and storage condition are the

* Corresponding author: SO, Postharvest Technology Section, HRC, BARI, Gazipur-1701, E-mail: mainuddinmolla@yahoo.com

(C) 2009 School of Agriculture and Rural Development, Bangladesh Open University, All rights reserved. 
most important quality control factors of chips preservation. Storage stability depends on packaging. Good packaging and storage condition extend the storage duration of chips.

In Bangladesh, few research works has been considered in this regard. Keeping this in view, the study was undertaken to find out the processing technique, packaging, quality aspect of chips from banana varieties and reduce postharvest losses and thus suggest ways and means for production of good quality banana chips.

\section{MATERIALS AND Methods}

The experiment was conducted in the laboratory of Postharvest Technology Section, Horticulture Research Centre (HRC) under Bangladesh Agricultural Research Institute (BARI), Joydebpur, Gazipur. Fully mature Sabri, BARI Kola-1 and BARI Kola-2 were collected from the farmer's field of Batajour, Bhaluka. Tasting salt, KMS, palm oil, knife, saucepan and spices were used in the experiment.

\section{Processing}

Fully mature Sobri, BARI Kola-1 and BARI Kola-2 were taken and washed with clean water. After peeling, the fruits were cut into $2 \mathrm{~mm}$ thickness. The slices were then weighed out, blanched 3 minutes in water at $95^{\circ} \mathrm{C}$ and immersed in $0.1 \%$ potassium metabisulphite (KMS) for 15 minutes using $2 \mathrm{~kg}$ of solution per $\mathrm{kg}$ of slice. After sieving water, the slices were dried in a mechanical dryer at $70^{\circ} \mathrm{C}$ for 1 hour and the rest of the period (about 4.5 hours) maintained at $60^{\circ} \mathrm{C}$ in view to using less oil in subsequent frying. Then the dried slices were fried in palm oil and stirred with narrow wooden stick. When the slices were turned to light yellow colour, the chips were put out from saucepan. The prepared chips were mixed with tasting salt and spices in a bowl. After this, the processed products were packed in different packaging materials viz.. i) Low density polyethylene pouch ii) Medium density polyethylene pouch and iii) Metalex foil pouch and stored in ambient temperature $\left(28-32^{\circ} \mathrm{C}\right)$. The flow sheets for preparation of fried banana chips are shown in Fig. 1.

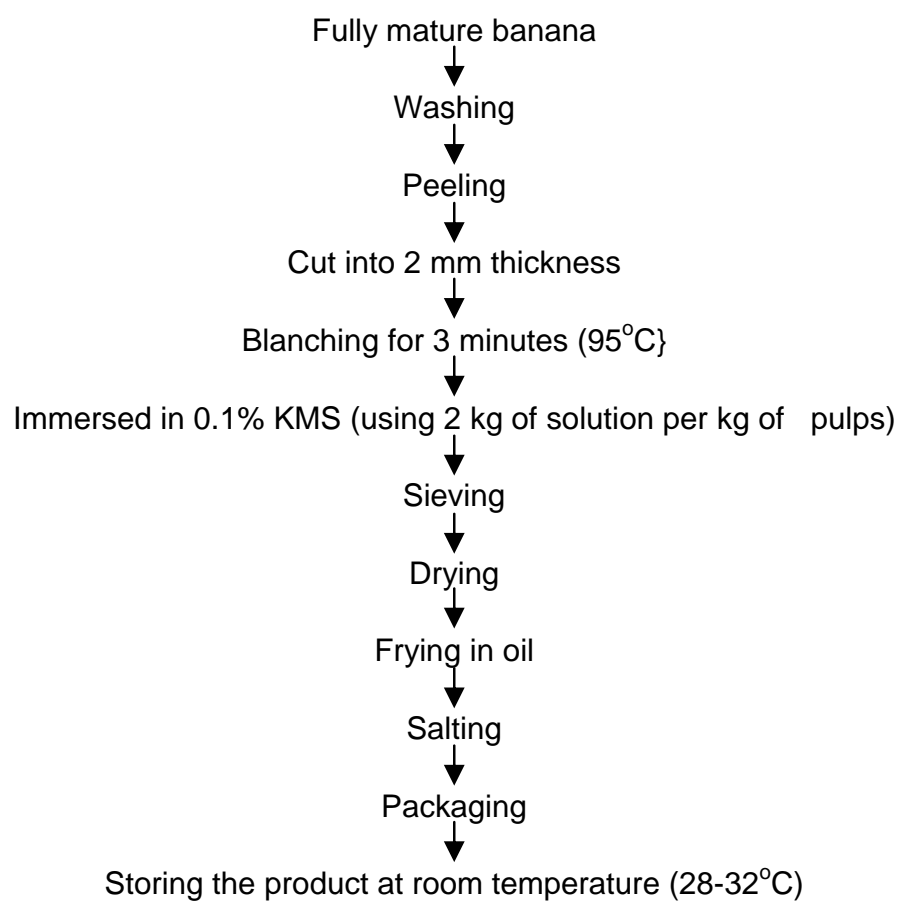

Fig. 1. Flow diagram for the preparation of fried banana chips 


\section{Analysis}

The prepared fresh chips and stored chips were analyzed for moisture content (\%), protein and weight gain according to Ranganna (1991).

\section{Determination of frying time}

The moisture content of freshly prepared fried chips should be $4.0 \%$. So, the frying time is determined as the time required to obtain $4 \%$ moisture content in fried chips from initial moisture content of dried slices (75\%).

\section{Determination of oil content}

The percentage of oil content was calculated as follows:

$$
\% \text { Oil content }=\frac{\text { Weight of oil }}{\text { Weight of sample }} \times 100
$$

\section{Determination of weight gain (\%)}

The percentage of weight gain was calculated as follows

$$
\% \text { Weight gain }=\frac{\text { Final weight }- \text { Initial weight }}{\text { Initial } \text { weight }} \times 100
$$

\section{Determination of moisture content}

Moisture content was determined according to Ranganna (1991). It was determined several times as in fresh banana pulps, prepared and stored chips.

\section{Determination of frying time and temperature}

Development of colour depends on frying time and temperature. A 1-9 point hedonic scale was used for a taste testing panel for selecting the desired frying time and temperature, which gave the best colour of chips.

\section{Sensory evaluation}

Sensory evaluations of the freshly prepared and stored chips were done by taste testing panel. The taste testing panels were consisting of 10 panelists. They were asked to evaluate the crispiness, taste, flavour, colour and overall acceptability by a scoring rate on a 9- point hedonic scale. 9=Like extremely, 8=Like very much, $7=$ Like moderately, 6=Like slightly, 5=Neither like nor dislike, 4=Dislike slightly, 3=Dislike moderately, 2=Dislike very much and 1=Dislike extremely. The different preferences as indicated by scores were evaluated by statistical methods. The analysis of variance method was used for this evaluation. The difference was quantified by Duncan's Multiple Range Test. The procedures of MSTAT was used for statistical analysis. Sensory evaluation based on taste testing panels was carried on freshly prepared and stored banana chips during 2 months of storage.

\section{Treatments for processing and packaging of banana chips}

$$
\begin{aligned}
\text { Factor A: } & \text { Variety } \\
& V_{1}=\text { Sabri } \\
& V_{2}=\text { BARI Kola-1 and } \\
& V_{3}=\text { BARI Kola-2 }
\end{aligned}
$$

Factor B: Packaging materials

$$
\begin{aligned}
& \mathrm{P}_{1}=\text { Low density polyethylene pouch (LDPE) } \\
& \mathrm{P}_{2}=\text { Medium density polyethylene pouch (MDPE) } \\
& \mathrm{P}_{3}=\text { Metalex foil pouch. }
\end{aligned}
$$

\section{Storage studies}

The changes in moisture content (\%), weight gain (\%), protein (\%), oil content (\%), crispiness, 
taste, flavour and colour of freshly prepared and stored chips were determined under room temperature $\left(28-32^{\circ} \mathrm{C}\right)$ at $\mathrm{O}$ day (On the day of packaging), 30 and 60 days of storage.

\section{RESULTS \\ Determination of the ratio of banana slices to oil}

Trial and error method was used for determination of banana slice to oil ratio. When banana slices were placed in the hot oil then the initial temperature dropped. Here, banana slices were fried at oil temperature of $170^{\circ} \mathrm{C}$. To maintain this desired temperatures, banana slices to oil ratio was chosen to give an initial temperature drop of $10^{\circ} \mathrm{C}$. The ratio of banana slice to oil was 2.5:10 (Table 1).

\section{Time and temperature required for frying to get $\mathbf{4 \%}$ moisture content in chips}

The rate of water removal depends on frying time and temperature. Getting $4 \%$ moisture content in banana chips required frying time was 3 minutes at $170^{\circ} \mathrm{C}$ (Table 2).

\section{Influence of frying temperature on colour of banana varieties chips}

Banana slices were fried at $170^{\circ} \mathrm{C}$ for different periods to get desired colour of chips maintaining with final moisture content of $4 \%$. For obtaining desired colour at $170^{\circ} \mathrm{C}$, minimum time of 3 minutes was acceptable (Table 2).

\section{Determination of oil content and protein of chips}

From the economic point of view and quality aspect, oil content of chips should be as low as possible. So, determination of oil content of chips was essential. The oil content of prepared chips for BARI Kola-1, BARI Kola-2 and Sabri were found $29 \%, 35 \%, 38 \%$ respectively at $170^{\circ} \mathrm{C}$ while the protein content was $2.37 \%, 0.55 \%$ and $1.19 \%$ respectively (Table 3 ).

Packaging and storage studies of banana chips in relation to moisture content (\%) and weight gain (\%)

Moisture content of fresh banana was $86 \%$. On the day of preparation ( 0 day), the moisture content of banana chips was maintained $5 \%$. During two months of storage periods, moisture content was increased in all the packaging materials (Table 4). During two months of storage, among the packaging system tested, the lowest moisture percent (5.4\%) was observed in samples packed in metalex foil. On the other hand, chips packed in low density polypropylene pouch obtained the highest percentage of moisture (5.9\%). During two months of storage periods, chips packed in all the packaging materials gained weight (Table 4).

\section{Sensory evaluation of fresh chips prepared from different banana varieties}

The mean score for crispiness, colour, taste, flavour and overall acceptability of stored chips prepared from different banana varieties are shown in Table 5. A one-way analysis of variance was conducted for sensory attributes based on the scores getting from taste testing panel. The DMRT test revealed that the colour of the chips prepared from Sabri variety secured the highest score over the chips of other varieties. But no significant difference was found between the colour preference of the chips prepared from the varieties BARI Kola-1 and BARI Kola-2. Crispiness of the stored chips prepared from the variety Sabri and BARI Kola-1 was preferred more than of BARI Kola-2. Among chips of different varieties, BARI Kola-2 scored the least crispiness. However, the taste, flavour and overall acceptability of the fstored chips of different banana varieties were not different statistically.

Table 1. Temperature drop as affected by banana slices to oil ratio.

\begin{tabular}{cc}
\hline Banana slices : oil & Initial temperature drop \\
\hline $1.25: 5$ & 12 \\
$1.88: 7.5$ & 15 \\
$2.5: 10$ & 10 \\
\hline
\end{tabular}


Table 2. Effect of frying temperature on colour of banana varieties chips

\begin{tabular}{llll}
\hline Variety & Oil temperature $\left(0^{\circ} \mathrm{C}\right)$ & Time required (min.) & Colour \\
\hline BARI Kola-1 & 170 & 3 & Yellowish \\
BARI Kola-2 & 170 & 3 & Dark and spot \\
Sabri Kola & 170 & 3 & Yellowish \\
\hline
\end{tabular}

Table 3. Oil and protein content of chips (stored products)

\begin{tabular}{lcc}
\hline Varieties & Oil content (\%) & Protein content (\%) \\
\hline BARI Kola-1 & 29 & 2.37 \\
BARI Kola-2 & 35 & 0.55 \\
Sabri Kola & 38 & 1.19 \\
\hline
\end{tabular}

Table 4. Packaging and storage studies of banana chips based on moisture content (\%) and weight gain (\%)

\begin{tabular}{lcc}
\hline $\begin{array}{c}\text { Storage peruiods } x \text { packaging } \\
\text { materials }\end{array}$ & Moisture content (\%) & Weight gain (\%) \\
\hline $\mathrm{OxP}_{1}$ & $5.0 \mathrm{~d}$ & $30.0 \mathrm{f}$ \\
$\mathrm{OxP}_{2}$ & $5.0 \mathrm{~d}$ & $30.0 \mathrm{f}$ \\
$\mathrm{OxP}_{3}$ & $5.0 \mathrm{~d}$ & $30.0 \mathrm{f}$ \\
$30 \times P_{1}$ & $5.6 \mathrm{abc}$ & $30.6 \mathrm{~b}$ \\
$30 \times P_{2}$ & $5.5 \mathrm{bc}$ & $30.1 \mathrm{~d}$ \\
$30 \times P_{3}$ & $5.30 \mathrm{~cd}$ & $30.70 \mathrm{e}$ \\
$60 \times P_{1}$ & $5.92 \mathrm{a}$ & $30.10 \mathrm{a}$ \\
$60 \times P_{2}$ & $5.85 \mathrm{ab}$ & $30.10 \mathrm{c}$ \\
$60 \mathrm{xP}$ & $5.40 \mathrm{c}$ & $30.12 \mathrm{~d}$ \\
\hline Level of significance & $\star \star$ & $\star \star$ \\
$\mathrm{CV}(\%)$ & 0.17 & 0.31 \\
\hline
\end{tabular}

$\mathrm{P}_{1}=$ Low density polypropylene pouch, $\mathrm{P}_{2}=$ Medium density polyethylene pouch, $\mathrm{P}_{3}=$ Metalez foil pouch.

Table 5. The mean score for crispiness, colour, taste, flavour and overall acceptability of banana chips (stored products) prepared from Sabri, BARI Kola-1 and BARI Kola-2

\begin{tabular}{lccccc}
\hline \multicolumn{1}{c}{$\begin{array}{c}\text { Variety used to prepare } \\
\text { Chips }\end{array}$} & \multicolumn{5}{c}{ Sensory attributes } \\
\cline { 2 - 6 } & Crispiness & Colour & Taste & Flavour & $\begin{array}{c}\text { Overall } \\
\text { acceptability }\end{array}$ \\
\hline Sabri & $9.20 \mathrm{a}$ & $9.00^{\mathrm{a}}$ & $7.70^{\mathrm{a}}$ & 7.10 & 8.48 \\
BARI Kola-1 & $8.50 \mathrm{a}$ & $6.60^{\mathrm{b}}$ & $7.40^{\mathrm{a}}$ & 6.20 & 7.20 \\
BARI Kola-2 & $7.50 \mathrm{~b}$ & $6.20^{\mathrm{b}}$ & $6.90^{\mathrm{a}}$ & 6.03 & 6.60 \\
\hline Level of significance & $*$ & $* *$ & $*$ & $\mathrm{~ns}$ & $\mathrm{~ns}$ \\
\hline
\end{tabular}

*Means followed by a common letter in a column are not significantly different at $5 \%$ level by DMRT

\section{Discussion}

Considering oil content and protein, BARI Kola-1 was found most suitable compared to BARI Kola2 and Sabri. This might be due to different cultivars differ in the characters affected by osmotic mutation and botanical origins. But observing the appearance of visual colour, Sabri kola was found most suitable for its bright colour. The appearance and brightness of colour might be depends on pulp quality, especially the porosity of pulp texture of different banana variety. In term of crispiness, BARI Kola-2 secured least score. This might be due to its porosity. The moisture content of chips is dependent on relative humidity of the storage structure. During two months storage, the increased moisture content might be due to absorption of moisture through sealing error. During storage, the moisture content and relative humidity was low. For retaining crispiness, chips stored for short period was also helpful. These results are an agreement with Rahman and Shams-Ud-Din (2003). 
Chips packed in all packaging materials gained weight. This might be due to absorbed moisture and experimental error. The results are an agreement with Molla, et.al. (2006).

The study indicated that chips packed in metalex foil pouch performed the best. This might be due to its double layer of polyethylene and chips packed in low density polypropylene pouch secured the lowest score. This might be due to its single layer of polyethylene. Islam and Shams-Ud-Din (2003) recommended that high density or laminated aluminum foil is suitable for long time storage of chips. Rahman and Shams-Ud-Din (2003) found that chips packed in low density polyethylene shortened the storage periods of chips.

\section{CONCLUSION}

Considering the appearance of visual colour, chips prepared from Sabri kola was found most suitable for its bright colour. During two months storage, based on taste teting panel, no statistically difference was found among the prepared chips from Sabri kola, BARI Kola-1 and BARI Kola-2 for their crispiness, taste, flavour and overall acceptability. However, it can be mentioned here, the preparation of banana chips is very simple and can easily be processed in rural areas where modern facilities of processing do not exist. Many food industries also can adopt the procedure for medium and large scale processing. Establishment of small-scale processing unit at grower's level could utilize the banana for processing of chips ultimately which contributes to minimize postharvest losses of banana and generates income to the growers.

\section{ACKNOWLEDGEMENT}

The author feels proud to express his heartiest sense of gratitude, sincere appreciation and indebtness to his respect and honorable Director, Md. Yousuf Mian and Dr. M.A.Jalil Bhuyan, Principal Scientific Officer, Postharvest Technology Section, Horticulture Research centre (HRC), BARI, Gazipur for their endless encouragement, valuable advice and providing necessary facilities during conduct this study.

\section{LiteratuRE Cited}

Amiruzzaman, N.1990. Post harvest handling and processing of fruits and vegetables. In:Kitchen Gardening and Homestead productive Activities.CIRDAP Action Research Series No. 11. p. 22.

Anand, J.C., S.B. Maini and B. Diwan. 1982. A Simple way to preserve potato for chips making J. Food Sci. Technol. 19, 267.

BBS. 2006. Statistical yearbook of Bangladesh. Bangladesh Bureau of Statistics, Ministry of Planning, Dhaka, Bangladesh. pp.158-159.

Islam, M. F. and M. Shams-Ud-Din. 2003. Studies on processing and storage of cassava chips. M.S. thesis, Department of Food Technology and Rural Industries, Bangladesh Agricultural University, Mymensingh, May, 2003.

Khader, A.A. 1992. Post harvest Technology of Horticultural crops. 2nd ed. Univ. of California. Div. of agric and Natural Resurces. Publication. No. 3311.

Molla, M. M., Alamgir Hossain. M., Nasrin, T. A. A., Sheel. S. and Islam M. N. 2007. Study on the preparation of shelf stable ready to serve (RTS) beverages based on bael pulp. Bangladesh Journal of Agricultural Research. 32(4), 573-586.

Momen, M.N., M.A.Rahim, A.M. Farooque and M. S. H. choudhury.1993. Effect of some Coating materials and physical measures on the prolongation of shelf life of banana. Agric., 4(1-2), 41-51.

Rahman, M. and Shams-Ud-Din, Md. 2003. Studies on processing and storage of papaya chips, M.S. thesis, Department of Food Technology and Rural Industries, Bangladesh Agricultural University, Mymensingh, November 2003.

Ranganna. S. 1991. Hand Book of Analysis and Quality Control for Fruit and Vegetable Products. Tata Mc Graw-Hill Publishing Company Ltd. New Delhi. India. 1112 p. 